
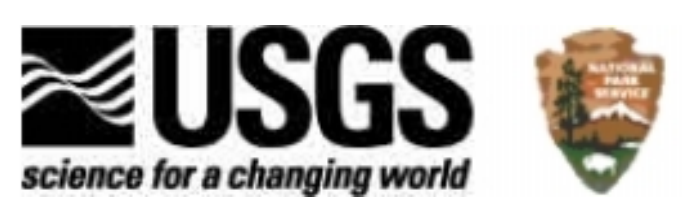

\title{
Coastal Vulnerability Assessment of Dry Tortugas National Park to Sea-Level Rise
}

By Elizabeth A. Pendleton, E. Robert Thieler, and S. Jeffress Williams

Any use of trade, firm, or product names is for descriptive purposes only and does not imply endorsement by the U.S. Government

\section{Open-File Report 2004-1416}

U.S. Department of the Interior U.S. Geological Survey 


\title{
U.S. Department of the Interior
}

\author{
Gale A. Norton, Secretary
}

\section{U.S. Geological Survey \\ Charles G. Groat, Director}

\section{U.S. Geological Survey, Reston, Virginia \\ For Additional Information: \\ See the National Park Unit Coastal Vulnerability study at http://woodshole.er.usgs.gov/project-pages/nps.cvi/, the National Coastal Vulnerability study at http://woodshole.er.usgs.gov/project-pages/cvi/, or view the USGS online fact sheet for this project in PDF format at http://pubs.usgs.gov/fs/fs095-02/.}

Dry Tortugas National Park Web pages are at http://www.nps.gov/drto/index.htm.

Contact:

http://woodshole.er.usgs.gov/project-pages/nps-cvi/ Telephone: 508-548-8700

Rebecca Beavers

National Park Service

Natural Resource Program Center

Geologic Resources Division

P.0. Box 25287

Denver, CO 80225-0287

Rebecca Beavers@nps.gov

Telephone: 303-987-6945

For more information on the USGS - the Federal source for science about the Earth, its natural and living resources, natural hazards, and the environment:

World Wide Web: http://www.usgs.gov

Telephone: 1-888-ASK-USGS

Although this report is in the public domain, permission must be secured from the individual copyright owners to reproduce any copyrighted material contained within this report. 


\section{Contents}

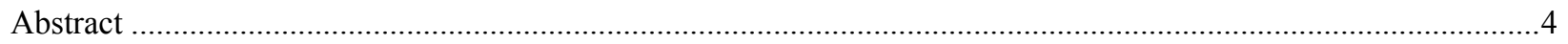

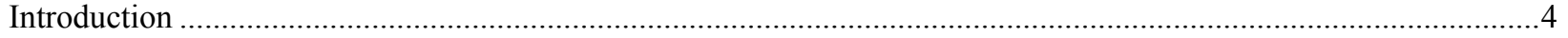

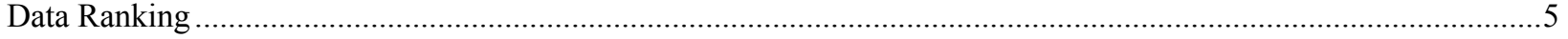

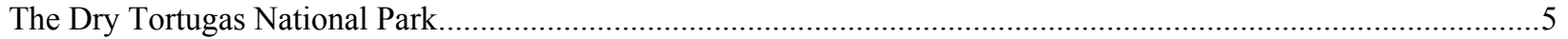

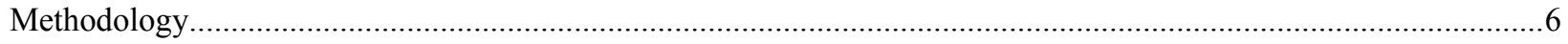

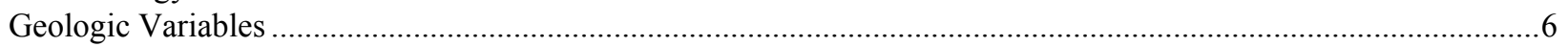

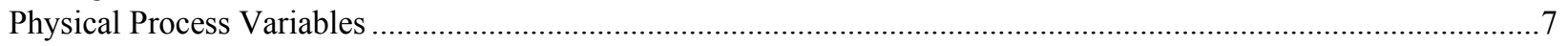

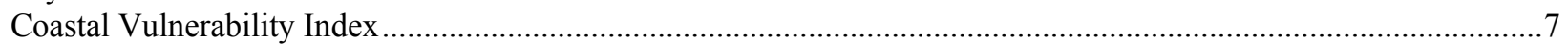

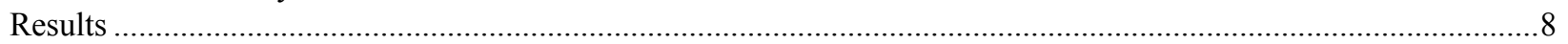

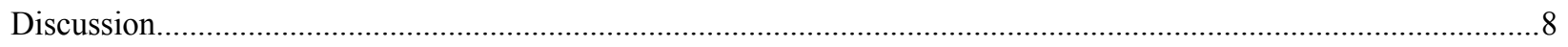

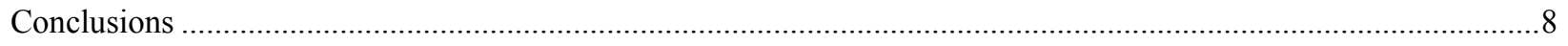

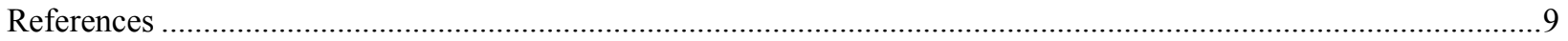

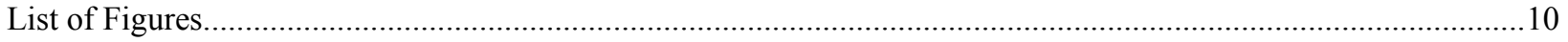

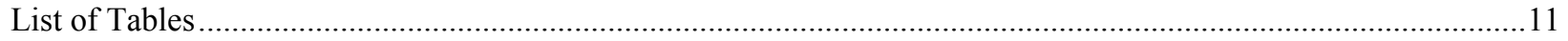




\title{
Coastal Vulnerability Assessment of Dry Tortugas National Park to Sea-Level Rise
}

\author{
By Elizabeth A. Pendleton, E. Robert Thieler, S. and Jeffress Williams
}

\begin{abstract}
A coastal vulnerability index (CVI) was used to map the relative vulnerability of the coast to future sealevel rise within Dry Tortugas National Park in Florida. The CVI ranks the following in terms of their physical contribution to sea-level rise-related coastal change: geomorphology, regional coastal slope, rate of relative sea-level rise, historical shoreline change rates, mean tidal range and mean significant wave height. The rankings for each input variable were combined and an index value calculated for 1-minute grid cells covering the park. The CVI highlights those regions where the physical effects of sea-level rise might be the greatest. This approach combines the coastal system's susceptibility to change with its natural ability to adapt to changing environmental conditions, yielding a quantitative, although relative, measure of the park's natural vulnerability to the effects of sea-level rise. The CVI provides an objective technique for evaluation and long-term planning by scientists and park managers. Dry Tortugas National Park consists of relatively stable to washover-dominated portions of carbonate beach and man-made fortification. The areas within Dry Tortugas that are likely to be most vulnerable to sea-level rise are those with the highest rates of shoreline erosion and the highest wave energy.
\end{abstract}

\section{Introduction}

The National Park Service (NPS) is responsible for managing nearly 12,000 km (7,500 miles) of shoreline along oceans and lakes. In 2001, the U.S. Geological Survey (USGS), in partnership with the NPS Geologic Resources Division, began conducting hazard assessments of future sea-level change by creating maps to assist NPS in managing its valuable coastal resources. This report presents the results of a vulnerability assessment for Dry Tortugas National Park, highlighting areas that are likely to be most affected by future sea-level rise.

Global sea level has risen approximately 18 centimeters (7.1 inches) in the past century (Douglas, 1997). Climate models predict an additional rise of $48 \mathrm{~cm}$ (18.9 in.) by 2100 (IPCC, 2002), which is more than double the rate of rise for the 20th century. Potential coastal impacts of sea-level rise include shoreline erosion, saltwater intrusion into groundwater aquifers, inundation of wetlands and estuaries, and threats to cultural and historic resources as well as infrastructure. Predicted accelerated global sea-level rise has generated a need in coastal geology to determine the likely response of a coastline to sea-level rise. However, an accurate and quantitative approach to predicting coastal change is difficult to establish. Even the kinds of data necessary to predict shoreline response are the subject of scientific debate. A number of predictive approaches have been proposed (National Research Council, 1990 and 1995), including:

1. extrapolation of historical data (e.g., coastal erosion rates),

2. static inundation modeling,

3. application of a simple geometric model (e.g., the Bruun Rule),

4. application of a sediment dynamics/budget model, or

5. Monte Carlo (probabilistic) simulation based on parameterized physical forcing variables.

However, each of these approaches has inadequacies or can be invalid for certain applications (National Research Council, 1990). Additionally, shoreline response to sea-level change is further complicated by human modification of the natural coast such as beach nourishment projects, and engineered structures such as seawalls, revetments, groins, and jetties. Understanding how a natural or modified coast will respond to sea-level change is essential to preserving vulnerable coastal resources. 
The primary challenge in predicting shoreline response to sea-level rise is quantifying the important variables that contribute to coastal evolution in a given area. In order to address the multi-faceted task of predicting sea-level rise impact, the USGS has implemented a methodology to identify areas that may be most vulnerable to future sea-level rise (see Hammar-Klose and Thieler, 2001). This technique uses different ranges of vulnerability (low to very high) to describe a coast's susceptibility to physical change as sea level rises. The vulnerability index determined here focuses on six variables that strongly influence coastal evolution:

1. Geomorphology

2. Historical shoreline change rate

3. Regional coastal slope

4. Relative sea-level change

5. Mean significant wave height

6. Mean tidal range

These variables can be divided into two groups: 1) geologic variables and 2) physical process variables. The geologic variables are geomorphology, historic shoreline change rate, and coastal slope; they account for a shoreline's relative resistance to erosion, long-term erosion/accretion trend, and its susceptibility to flooding, respectively. The physical process variables include significant wave height, tidal range, and sea-level change, all of which contribute to the inundation hazards of a particular section of coastline over time scales from hours to centuries. A relatively simple vulnerability ranking system (Table 1) allows the six variables to be incorporated into an equation that produces a coastal vulnerability index (CVI). The CVI can be used by scientists and park managers to evaluate the likelihood that physical change may occur along a shoreline as sea level continues to rise.

Additionally, NPS staff will be able to incorporate information provided by this vulnerability assessment technique into general management plans

\section{Data Ranking}

Table 1 shows the six variables described in the Introduction, which include both quantitative and qualitative information. The five quantitative variables are assigned a vulnerability ranking based on their actual values, whereas the non-numerical geomorphology variable is ranked qualitatively according to the relative resistance of a given landform to erosion. Shorelines with erosion/accretion rates between -1.0 and $+1.0 \mathrm{~m} / \mathrm{yr}$ are ranked as being of moderate vulnerability in terms of that particular variable. Increasingly higher erosion or accretion rates are ranked as correspondingly higher or lower vulnerability. Regional coastal slopes range from very high vulnerability, $<0.3$ percent, to very low vulnerability at values $>1.2$ percent. The rate of relative sea-level change is ranked using the modern rate of eustatic rise $(1.8 \mathrm{~mm} / \mathrm{yr})$ as very low vulnerability. Since this is a global or "background" rate common to all shorelines, the sea-level rise ranking reflects primarily local to regional isostatic or tectonic adjustment. Mean wave height contributions to vulnerability range from very low $(<0.55 \mathrm{~m})$ to very high $(>1.25 \mathrm{~m})$. Tidal range is ranked such that microtidal $(<1 \mathrm{~m})$ coasts are very high vulnerability and macrotidal $(>6$ m) coasts are very low vulnerability.

\section{The Dry Tortugas National Park}

The atoll-like, coral and carbonate sand islands of the Dry Tortugas lie about $110 \mathrm{~km}$ ( 70 miles) west of Key West in Florida (Figure 1). These islands formed during the Holocene as wave processes in combination with a slow-steady rise in sea-level worked limestone and coral into mounds of carbonate sand with thicknesses ranging from 14 - $18 \mathrm{~m}$ ( 45 - $55 \mathrm{ft}$ ) (Shinn et al, 1977). These islands were named Las Tortugas by Spanish explorer Ponce de Leon because of the large number of turtles inhabiting these islands. Later Dry was added to the name on nautical charts to let mariners know that there was no fresh water on the islands. 
The largest brick structure in the Western Hemisphere is located on Garden Key and is nineteenth century Fort Jefferson. Construction began in 1846 as part of the US coastal fortification efforts following the War of 1812, but the fort was never completed. Fort Jefferson was used as a military prison during the Civil War, but was abandoned by the Army in 1874. In 1908 the Dry Tortugas were declared a wildlife refuge, then in 1935 Fort Jefferson National Monument was established, creating the first underwater park unit. In 1992 the area became Dry Tortugas National Park.

Hurricanes passing through the Gulf of Mexico are always reshaping the islands and leaving their mark on Fort Jefferson. During 2004 when Hurricane Charley passed over the Dry Tortugas, the landbridge connecting Bush Key to Garden Key washed over, but within a few hours the spit reformed (M. Ryan, personal communication, Oct. 29, 2004). Although storm impacts are not directly addressed in this report it is important to acknowledge their role in the dynamic evolution of the Dry Tortugas. Further the authors acknowledge that the islands of the Dry Tortugas owe their continued existence to coral reef productivity, which is vulnerable to not only expected accelerated sealevel rise, but also hurricane damage, increased water temperature, boat anchoring, coral disease, and fishing. Coral reef health and productivity is not directly addressed in this methodology.

\section{Methodology}

In order to develop a database for a park-wide assessment of coastal vulnerability, data for each of the six variables mentioned above were gathered from state and federal agencies (Table 2). The database is based on that used by Thieler and Hammar-Klose (1999) and loosely follows an earlier database developed by Gornitz and White (1992). A comparable assessment of the sensitivity of the Canadian coast to sea-level rise is presented by Shaw and others (1998). Also a report on the effects of rising seas on coral reefs in South Florida was presented by Lidz and Shinn (1991).

The database was constructed using a 1:40,000-scale shoreline for Dry Tortugas that was produced by the Florida Department of Environmental Protection. Data for each of the six variables (geomorphology, shoreline change, coastal slope, relative sea-level rise, significant wave height, and tidal range) were added to the shoreline attribute table (Figure 2). Ideally, a 1-minute (approximately $1.5 \mathrm{~km}$ ) grid is used to divide the shoreline into units in which each variable will be defined. However, due to the configuration and size of the islands of the Dry Tortugas, a grid was not feasible. All of the islands except middle key (the smallest) were divided into two shoreline segments generally along their long axis. Next each variable in each grid cell was assigned a vulnerability value from 1-5 (1 is very low vulnerability, 5 is very high vulnerability) based on the potential magnitude of its contribution to physical changes on the coast as sea level rises (Table 1).

\section{Geologic Variables}

The geomorphology variable expresses the relative erodibility of different landform types (Table 1). These data were derived from USGS 1-meter resolution digital orthophotos of Dry Tortugas (Table 2). In addition, field visits were made within the park to ground-truth the geomorphologic classification. All areas of the Dry Tortugas are considered very high vulnerability with the exception of Loggerhead Key, which was classified as high vulnerability because of the presence of substantial stretches of beach rock that has helped protect the island and what remains of the Carnegie Institute Lab (Ginsburg, 1953) (Figure 3A). Fort Jefferson and the moat wall surrounding it are classified as very high vulnerability, even though the fort is 15 meters higher than anything else in the Dry Tortugas. This classification was made because the Fort is built upon carbonate sand, and the human resources required to maintain the Fort over time are less frequent than the replenishment of carbonate sand through biologic and physical processes (Figure 3A-E).

Shoreline erosion and accretion rates for Dry Tortugas were calculated using digitized shorelines from NOAA T-sheets, Nautical Charts, and USGS aerial photography (Table 2). Shoreline rates of change (m/yr) were calculated at $200 \mathrm{~m}$ intervals (transects) along the coast using Digital Shoreline Analysis System (DSAS) software (http://woodshole.er.usgs.gov/project-pages/dsas/) to derive the rate of shoreline change. The change rates for each transect within each grid cell were averaged to determine the shoreline change value used here, with positive numbers indicating accretion and negative numbers indicating erosion. Shoreline change rates on Dry Tortugas 
range from $2 \mathrm{~m} / \mathrm{yr}$ of accretion (low vulnerability) to almost greater than $2 \mathrm{~m} / \mathrm{yr}$ of erosion (very high vulnerability) (Figure 4A-C).

Regional coastal slope is an indication of the relative vulnerability to inundation and the potential rapidity of shoreline retreat because low-sloping coastal regions should retreat faster than steeper regions (Pilkey and Davis, 1987). The regional slope of the coastal zone was calculated from a grid of topographic and bathymetric elevations extending $5 \mathrm{~km}$ landward and seaward of the shoreline. Elevation data were obtained from the National Geophysical Data Center (NGDC) as gridded topographic and bathymetric elevations at 0.1 meter vertical resolution for 3 arcsecond $(\sim 90 \mathrm{~m})$ grid cells. Regional coastal slopes for Dry Tortugas all fall within the high vulnerability category (0.3 - $0.6 \%$ slope $)$.

\section{Physical Process Variables}

The relative sea-level variable is derived from the change in annual mean water elevation over time as measured at tide gauge stations along the coast. The rate of sea-level rise for Key West in FL is $2.27+/-0.09 \mathrm{~mm} / \mathrm{yr}$ based on 87 years of data (Maul and Martin, 1993; Zervas, 2001). This variable inherently includes both eustatic sea-level rise as well as regional sea-level rise due to isostatic and tectonic adjustments of the land surface. Relative sea-level change data are a historical record, and thus portray only the recent sea-level trend ( $<150$ years). Relative sea-level rise for Dry Tortugas falls within low vulnerability based on water elevation data at Key West in Florida..

Mean significant wave height is used here as a proxy for wave energy which drives coastal sediment transport. Wave energy is directly related to the square of wave height:

$$
E=1 / 8 \rho g H^{2}
$$

where $E$ is energy density, $H$ is wave height, $\rho$ is water density and $g$ is acceleration due to gravity. Thus, the ability to mobilize and transport coastal sediments is a function of wave height squared. In this report, we use hindcast nearshore mean significant wave height data for the period 1976-95 obtained from the U.S. Army Corps of Engineers Wave Information Study (WIS) (Hubertz and others, 1996). The model wave heights were compared to historical measured wave height data obtained from the NOAA National Data Buoy Center to ensure that model values were representative of the study area. For Dry Tortugas, mean significant wave heights are between 0.5 and $0.8 \mathrm{~m}$, which represents very low and low vulnerability, respectively.

Tidal range is linked to both permanent and episodic inundation hazards. Tide range data were obtained from NOAA/NOS for a tide gauge at Key West, FL. Dry Tortugas is classified as very high vulnerability (less than 1 meter) with respect to tidal range.

\section{Coastal Vulnerability Index}

The coastal vulnerability index (CVI) presented here is the same as that used in Thieler and Hammar-Klose (1999) and is similar to that used in Gornitz and others (1994), as well as to the sensitivity index employed by Shaw and others (1998). The CVI allows the six variables to be related in a quantifiable manner that expresses the relative vulnerability of the coast to physical changes due to future sea-level rise. This method yields numerical data that cannot be equated directly with particular physical effects. It does, however, highlight areas where the various effects of sea-level rise may be the greatest. Once each section of coastline is assigned a vulnerability value for each specific data variable, the coastal vulnerability index (CVI) is calculated as the square root of the product of the ranked variables divided by the total number of variables;

$\mathrm{CVI}=\sqrt{\frac{\left(a^{*} b^{*} c^{*} d^{*} e^{*} f\right)}{6}}$

where, $\mathrm{a}=$ geomorphology, $\mathrm{b}=$ shoreline erosion/accretion rate, $\mathrm{c}=$ coastal slope, $\mathrm{d}=$ relative sea-level rise rate, $\mathrm{e}=$ mean significant wave height, and $\mathrm{f}=$ mean tide range. The calculated $\mathrm{CVI}$ value is then divided into 
quartile ranges to highlight different vulnerabilities within the park. The CVI ranges (low - very high) reported here apply specifically to Dry Tortugas National Park, and are not comparable to CVI ranges in other parks where the CVI has been employed (i.e. very high vulnerability means the same among parks; it's the numeric values that differ, such that a numeric value that equals very high vulnerability in one park may equal moderate vulnerability in another). To compare vulnerability between coastal parks, the national-scale studies should be used (Thieler and Hammar-Klose, 1999, 2000a, and 2000b). We feel this approach best describes and highlights the vulnerability specific to each park.

\section{Results}

The CVI values calculated for Dry Tortugas range from 8.16 to 18.3 . The mean CVI value is 13.5 ; the mode is 11.55 and the median is 12.65 . The standard deviation is 3.3 . The 25 th, 50 th, and 75 th percentiles are 9.0 , 13.0 and 15.0, respectively.

Figure 5 shows a map of the coastal vulnerability index for Dry Tortugas National Park. The CVI scores are divided into low, moderate, high, and very high-vulnerability categories based on the quartile ranges and visual inspection of the data. CVI values below 9.0 are assigned to the low vulnerability category. Values from 9.0 to 13.0 are considered moderate vulnerability. High-vulnerability values lie between 13.01 and 15.0. CVI values above 15.0 are classified as very high vulnerability. Figure 6 shows the percentage of Dry Tortugas shoreline in each vulnerability category. Coastal vulnerability was mapped for seven islands within the Dry Tortugas. Of this total, twenty-three percent of the mapped shoreline is classified as being at very high vulnerability due to future sea-level rise. Twenty-three percent is classified as high vulnerability, thirty-eight percent as moderate vulnerability, and sixteen percent as low vulnerability.

\section{Discussion}

The data within the coastal vulnerability index (CVI) show variability at different spatial scales (Figure 5). However, the ranked values for the physical process variables vary less over the extent of the shoreline. The value of the relative sea-level rise variable is constant at low vulnerability for the entire study area. The significant wave height vulnerability is low to very low. The tidal range is very high vulnerability $(<1 \mathrm{~m})$ for all of Dry Tortugas.

The geologic variables show the most spatial variability and thus have the most influence on CVI variability (Figure 5). Geomorphology in the park includes high vulnerability beachrock stabilized shoreline and very high vulnerability carbonate beach including areas with manmade structures. Vulnerability assessment based on historical shoreline change trends varies from low to very high (Figure 4A-E). Regional coastal slope is in the high vulnerability range over the entire extent of Dry Tortugas.

The area within the Dry Tortugas that may be most vulnerable to future sea-level rise (very high vulnerability) are the islands with the highest rates of shoreline change and high wave heights such as Middle key and East Key. The areas least vulnerable to sea-level rise may be the south facing shorelines of Bush and Long Key due to shoreline accretion and low wave energy.

The most influential variables in the CVI are geomorphology, historical shoreline change rates, and significant wave height; therefore they may be considered the dominant factors controlling how Dry Tortugas will evolve as sea level rises. Geomorphology and significant wave height only vary between high and very high and low and very low vulnerability, respectively; whereas the shoreline change variable ranges from low to very high.

\section{Conclusions}

The coastal vulnerability index (CVI) provides insight into the relative potential of coastal change due to future sea-level rise. The maps and data presented here can be viewed in at least two ways: 
1. as an indication of where physical changes are most likely to occur as sea level continues to rise; and

2. as a planning tool for the Dry Tortugas National Park.

As ranked in this study, geomorphology, historical rates of shoreline change, and significant wave height and are the most important variables in determining the spatial variability of the CVI for Dry Tortugas. Regional coastal slope, tidal range, and sea-level rise rate do not contribute to the spatial variability in the coastal vulnerability index.

Dry Tortugas National Park preserves a dynamic natural environment, which must be understood in order to be managed properly. The CVI is one way that park managers can assess objectively the natural factors that contribute to the evolution of the coastal zone, and thus how the park may evolve in the future.

\section{References}

Douglas, B.C., 1997, Global sea rise, a redetermination: Surveys in Geophysics, v. 18, p. $279-292$.

Ginsburg, R.N., 1953, Beachrock in South Florida: Journal of Sedimentary Petrology, v. 23, no. 2, p. 85-92.

Gornitz, V. and White, T.W. 1992, A coastal hazards database for the U.S. West Coast: ORNL/CDIAC-81, NDP-043C, 0ak Ridge National Laboratory, Oak Ridge, Tenn.

Gornitz, V.M., Daniels, R.C., White, T.W., and Birdwell, K.R., 1994, The development of a coastal vulnerability assessment database; Vulnerability to sea-level rise in the U.S. southeast: Journal of Coastal Research, Special Issue No. 12, p. 327-338.

Hammar-Klose, E.S., and Thieler, E.R., 2001, Coastal vulnerability to sea-level rise; A preliminary database for the U.S. Atlantic, Pacific, and Gulf of Mexico coasts: U.S. Geological Survey, Digital Data Series, DDS-68, CD-ROM. (Available online at: http://pubs.usgs.gov/dds/dds68/)

Hubertz, J.M., Thompson, E.F., and Wang, H.V., 1996, Wave information studies of U.S. coastlines; Annotated bibliography on coastal and ocean data assimilation: WIS Report 36, U.S. Army Engineer Waterways Experiment Station, Vicksburg, 31 p.

IPCC, 2002, Climate change 2001, the scientific basis; Contribution of working group I to the third assessment report of the Intergovernmental Panel on Climate Change (IPCC): Geneva, Switzerland, 563 p. (Also available on the Web at www.ipcc.ch).

Lidz, B.H., and Shinn, E.A., 1991, Paleoshorelines, reefs, and a rising sea, South Florida, USA: Journal of Coastal Research, v.1, no. 7, p 203-229.

Maul, G.A., and Martin, D.M., 1993, Sea level rise at Key West, Florida, 1846-1992; America's longest instrument record?: Geophysical Research Letters, v. 20, no. 18, p. 1955-1958.

National Research Council, 1990, Managing coastal erosion, Washington: National Academy Press, $163 \mathrm{p}$.

National Research Council, 1995, Beach nourishment and protection, Washington: National Academy Press, $334 \mathrm{p}$.

Pilkey, O.H., and Davis, T.W., 1987, An analysis of coastal recession models, North Carolina coast, in Nummedal, D., Pilkey, O.H., and Howard, J.D., eds., Sea-level Fluctuation and Coastal Evolution: SEPM (Society for Sedimentary Geology) Special Publications No. 41, Tulsa, Okla., p. 59-68.

Shaw, J., Taylor, R.B., Forbes, D.L., Ruz, M.H., and Solomon, S., 1998, Sensitivity of the Canadian coast to sea-level rise: Geological Survey of Canada Bulletin 505, $114 \mathrm{p}$.

Shinn, E.A., Hudson, J.H., Robbin, D.M., and Lidz, B., 1977, Topographic control and accumulation rate of some Holocene coral reefs, South Florida and Dry Tortugas: Proceedings, Third International Coral Reef Symposium, v. 2, p. 1-7.

Thieler, E.R., and Hammar-Klose, E.S., 1999, National assessment of coastal vulnerability to sea-level rise, U.S. Atlantic Coast: U.S. Geological Survey Open-File Report 99-593, 1 sheet. (Available online at: http://pubs.usgs.gov/of/of99-593/.)

Thieler, E.R., and Hammar-Klose, E.S., 2000a, National assessment of coastal vulnerability to sea-level rise, U.S. Pacific Coast: U.S. Geological Survey Open-File Report 00-178, 1 sheet. (Available online at: http://pubs.usgs.gov/of/of00-178/.)

Thieler, E.R., and Hammar-Klose, E.S., 2000b, National assessment of coastal vulnerability to sea-level rise, U.S. Gulf of Mexico Coast: U.S. Geological Survey Open-File Report 00-179, 1 sheet. (Available online at: http://pubs.usgs.gov/of/of00-179/.)

Zervas, C., 2001, Sea level variations of the United States 1854-1999: NOAA Technical Report NOS C0-OPS 36, 201 p. 


\section{List of Figures}

Figure 1. Location of Dry Tortugas National Park, Florida.

Figure 2. Shoreline segments for the Dry Tortugas. All of the islands were divided into two shoreline segments with the exception of middle key.

Figure 3. Index map for geomorphology photos. A) Loggerhead Key, B) Garden Key, C) Bush Key, D) Long Key, and E) Hospital Key.

Figure 3A. Loggerhead Key; the top photo shows beachrock along the shore which helps to stabilize the shoreline (high vulnerability); the bottom photo shows Loggerhead Key and the lighthouse. The islands are low elevation and sparsely vegetated (photos by Rebecca Beavers)

Figure 3B. Garden Key and Fort Jefferson; the top photo is a view of Fort Jefferson from the water approaching the docks (photo by Rebecca Beavers), the center photos shows the beach area near the boat docks, the bottom photos show the transition from carbonate beach (left) to moat wall (right) (very high vulnerability).

Figure 3C. Bush Key, the top photos show a view of the north side of Bush Key looking west toward Fort Jefferson (left photo) and looking east toward Long Key (right photo. The bottom photos show the center of Bush Key composed of large coral rubble (left photo) and the quieter water (lower wave energy) on the south side of Bush Key looking west toward Fort Jefferson (right photo) (very high vulnerability).

Figure 3D. Long Key; the top photos show the magnificent frigate bird rookery on Long Key (left photo) and the east side of Long Key (right photo) which experiences higher wave energy than the west side, which is largely covered in Mangroves (bottom photo) (very high vulnerability).

Figure 3E. Hospital Key; The top photo shows the slight aerial portion of Hospital Key, and the bottom photos shows a sign deterring trespassing to protect nesting birds (photos by Rebecca Beavers) (very high vulnerability).

Figure 4. Index map for historic shoreline change figures. Click on a box for a detailed view of historic shoreline change on A) Loggerhead Key, B) Garden Key, Bush Key, and Long Key, and C) Hospital Key, Middle Key, and East Key. Grey shaded areas are water and have been removed from the shoreline change figure.

Figure 4A. Historic shoreline change for Loggerhead Key.

Figure 4B. Historic shoreline change for Garden Key, Bush Key, and Long Key.

Figure 4C. Historic shoreline change for Hospital Key, Middle Key, and East Key .

Figure 5. Relative Coastal Vulnerability for Dry Tortugas National Park. The innermost color bar is the relative coastal vulnerability index (CVI). The remaining color bars are separated into the geologic variables (1-3) and physical process variables $(4-6)$. The very high vulnerability shoreline is located on East Key and Middle Key where rates of shoreline change have been highest. The low vulnerability shoreline is located on the south side of Bush Key and the west side of Long Key, where wave energy is low.

Figure 6. Percentage of Dry Tortugas shoreline in each CVI category. 


\section{List of Tables}

Table 1. Ranges for Vulnerability Ranking of Variables on the U.S. Atlantic and Gulf Coast.

Table 2. Sources of Data 


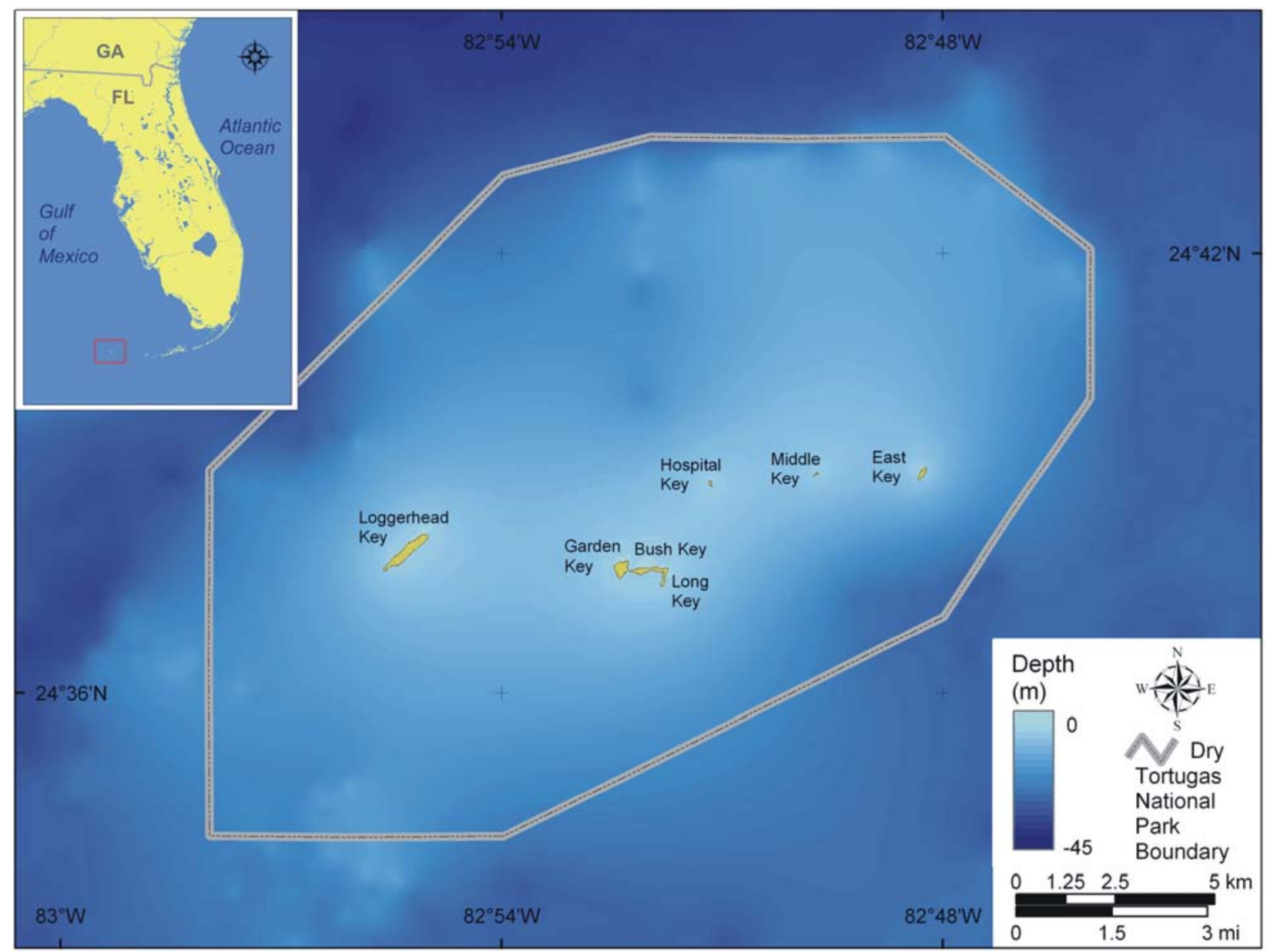

Figure 1. Location of Dry Tortugas National Park, Florida. 


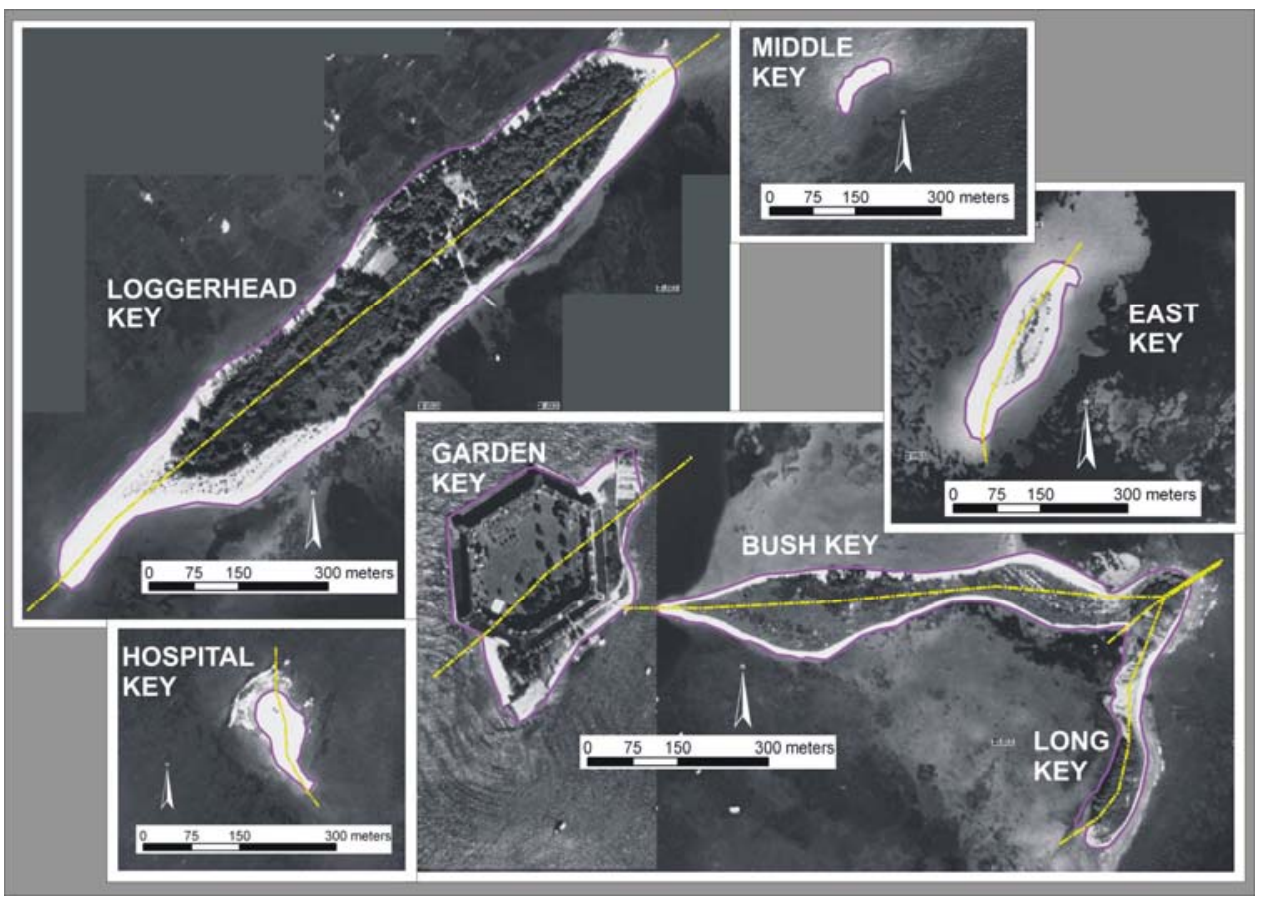

Figure 2. Shoreline segments for the Dry Tortugas. All of the islands were divided into two shoreline segments with the exception of middle key. 


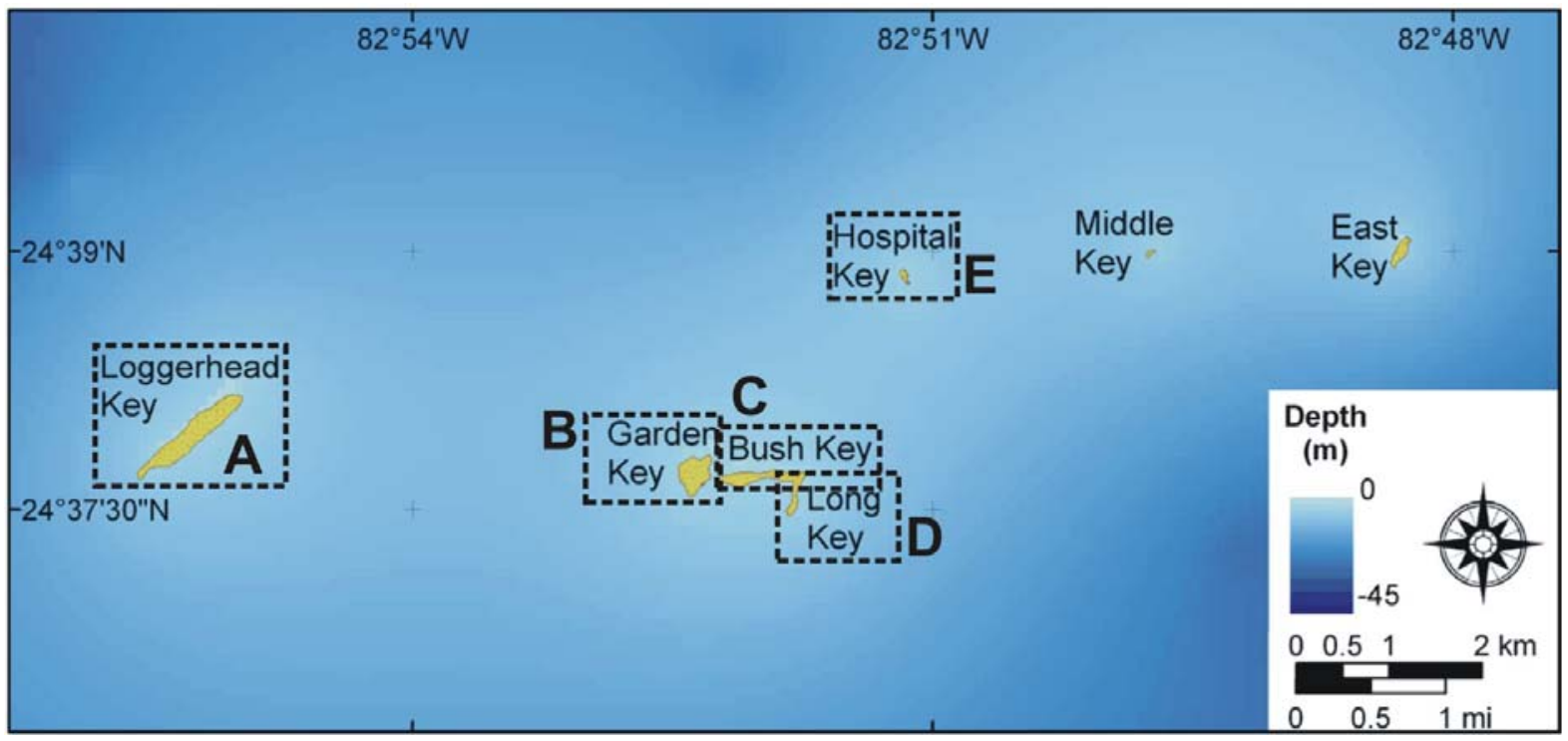

Figure 3. Index map for geomorphology photos. A) Loggerhead Key, B) Garden Key, C) Bush Key, D) Long Key, and E) Hospital Key. 


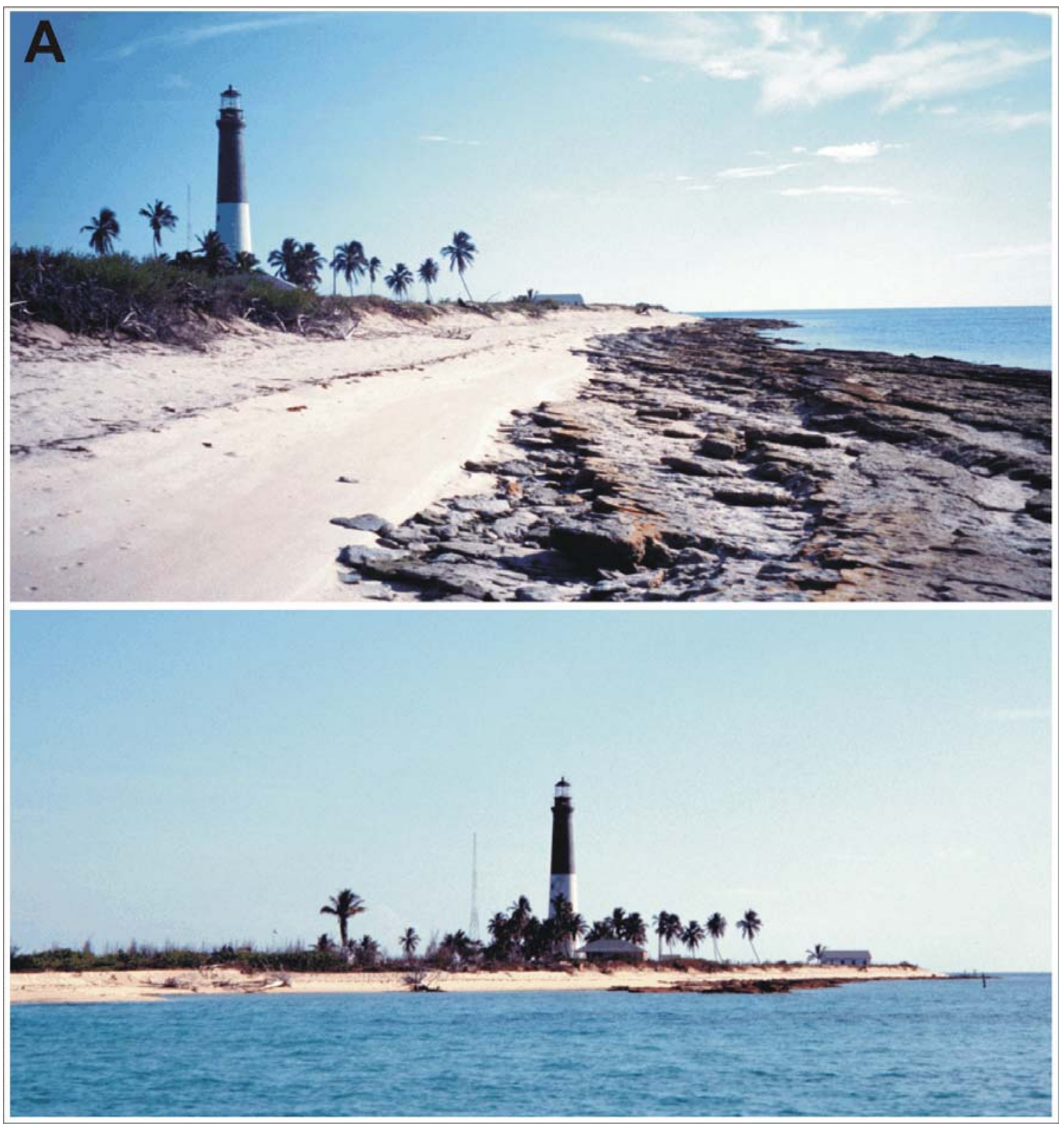

Figure 3A. Loggerhead Key; the top photo shows beachrock along the shore which helps to stabilize the shoreline (high vulnerability); the bottom photo shows Loggerhead Key and the lighthouse. The islands are low elevation and sparsely vegetated (photos by Rebecca Beavers) 

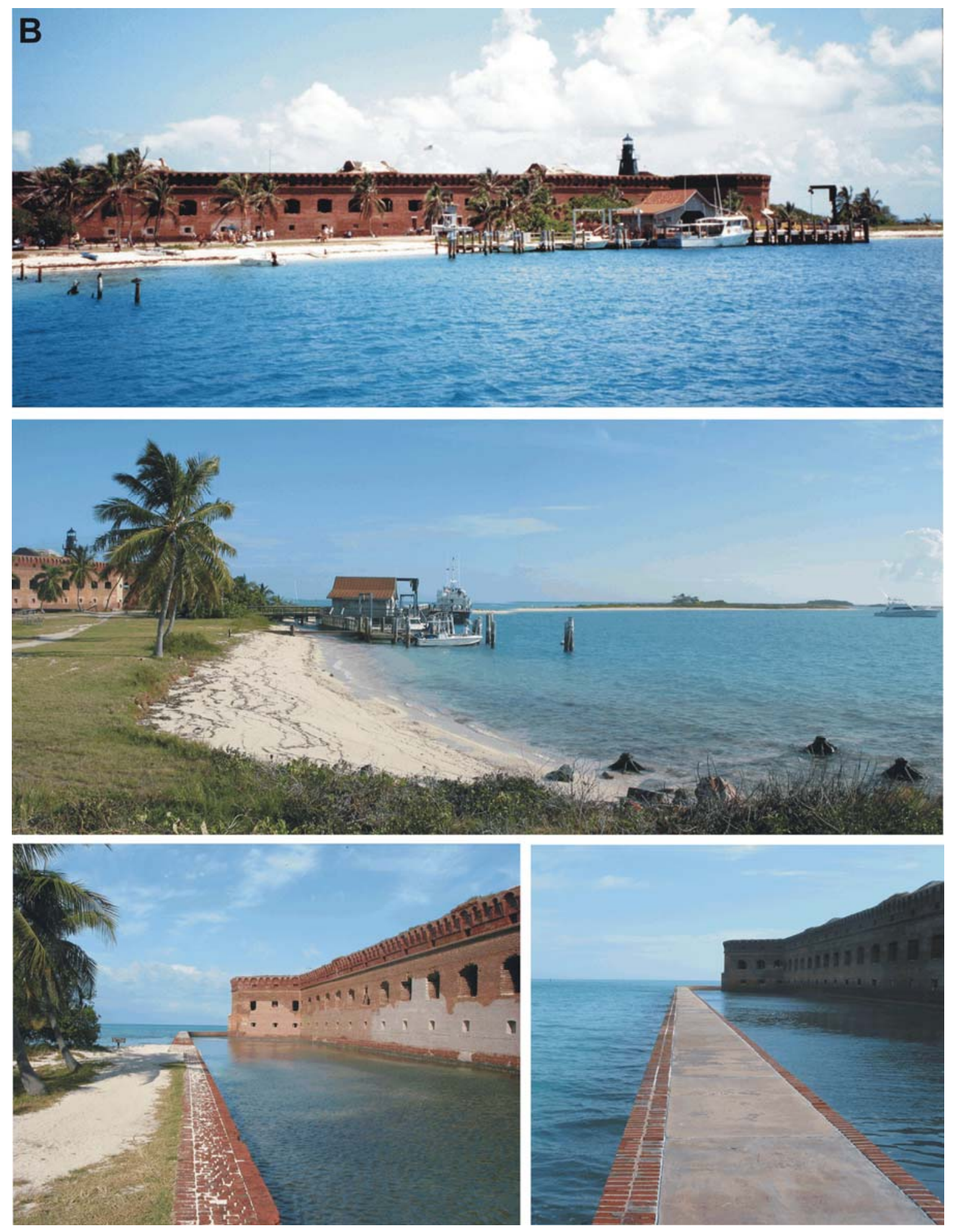

Figure 3B. Garden Key and Fort Jefferson; the top photo is a view of Fort Jefferson from the water approaching the docks (photo by Rebecca Beavers), the center photos shows the beach area near the boat docks, the bottom photos show the transition from carbonate beach (left) to moat wall (right) (very high vulnerability). 


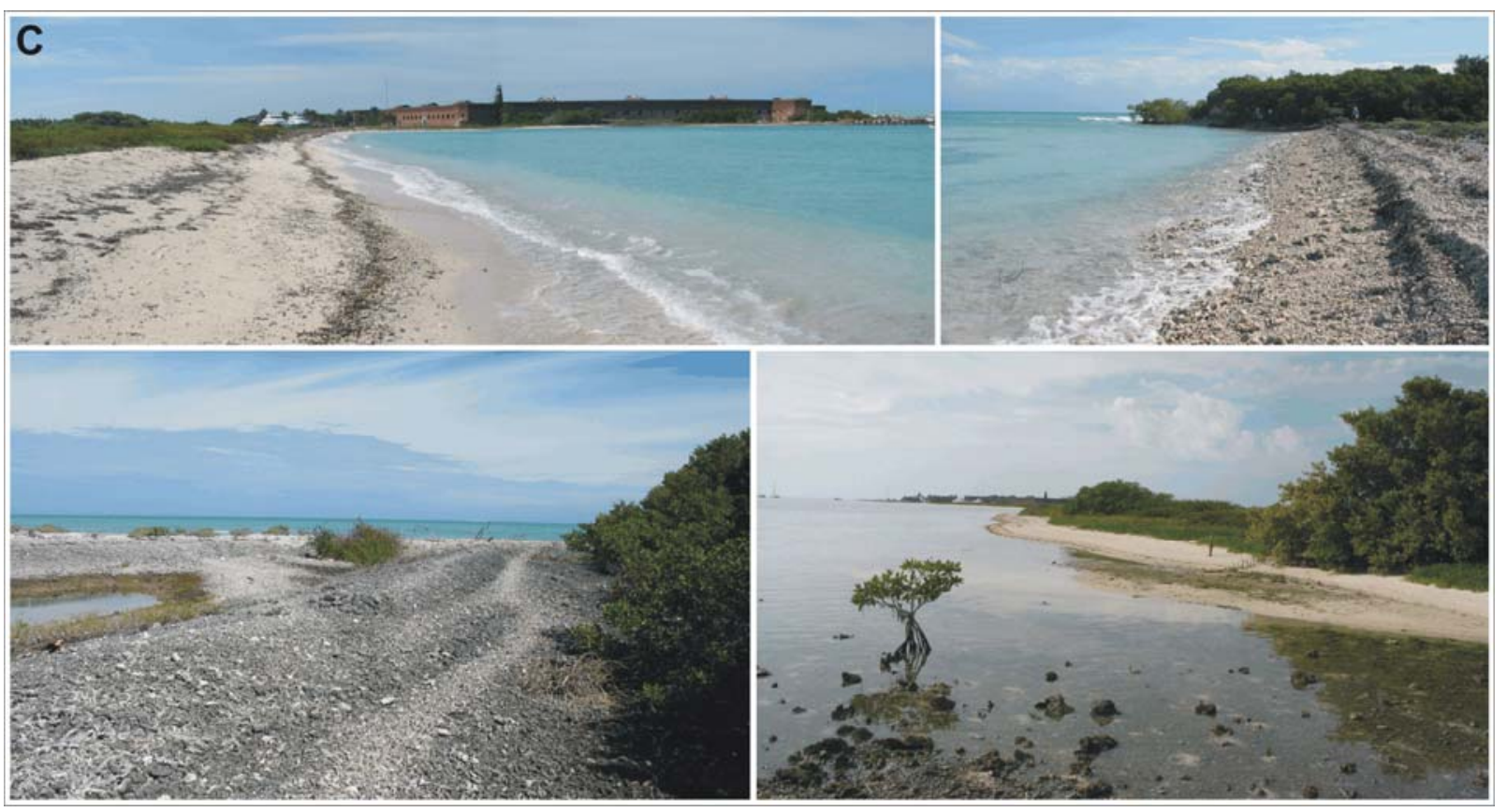

Figure 3C. Bush Key, the top photos show a view of the north side of Bush Key looking west toward Fort Jefferson (left photo) and looking east toward Long Key (right photo. The bottom photos show the center of Bush Key composed of large coral rubble (left photo) and the quieter water (lower wave energy) on the south side of Bush Key looking west toward Fort Jefferson (right photo) (very high vulnerability). 

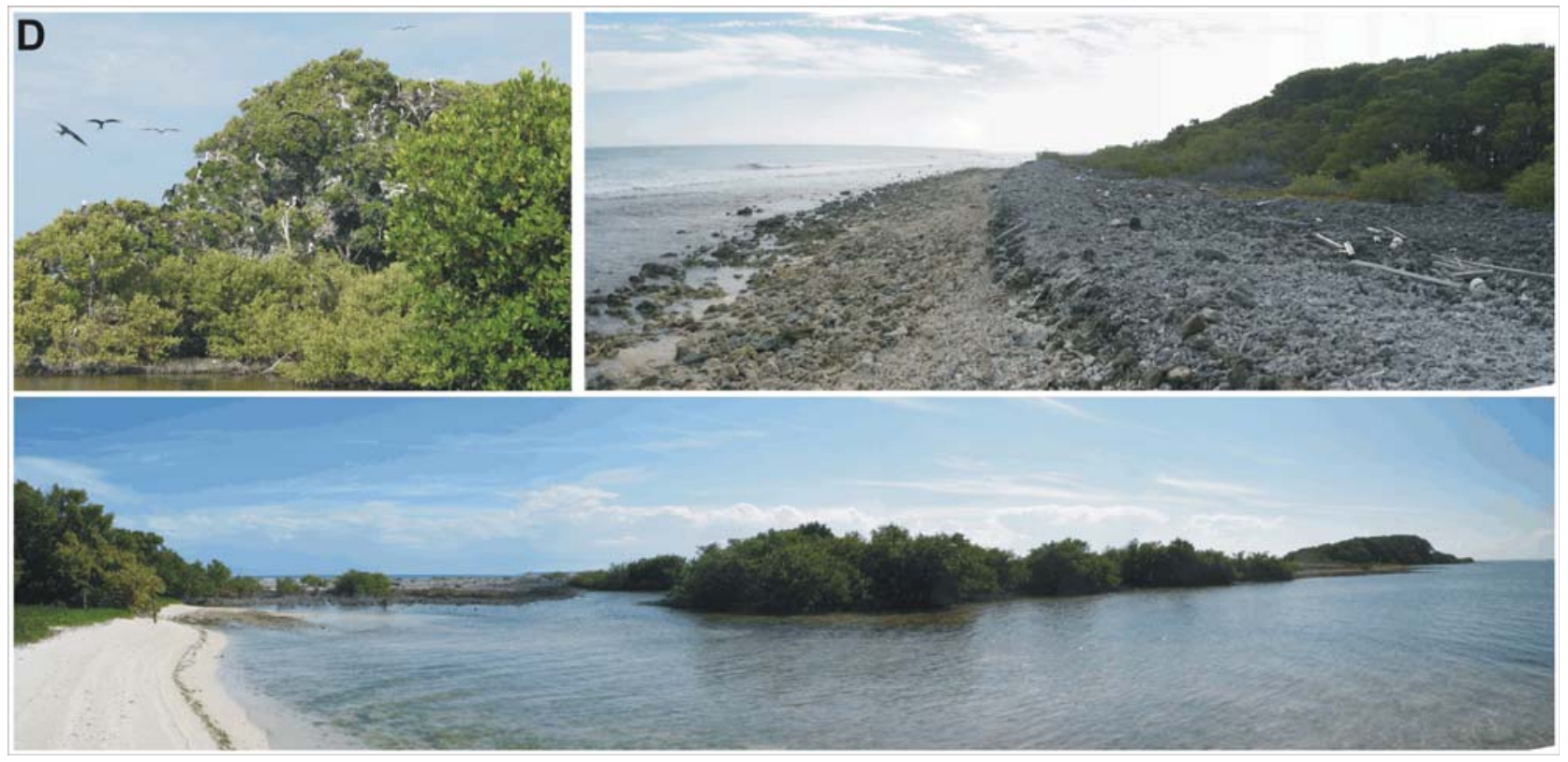

Figure 3D. Long Key; the top photos show the magnificent frigate bird rookery on Long Key (left photo) and the east side of Long Key (right photo) which experiences higher wave energy than the west side, which is largely covered in Mangroves (bottom photo) (very high vulnerability). 

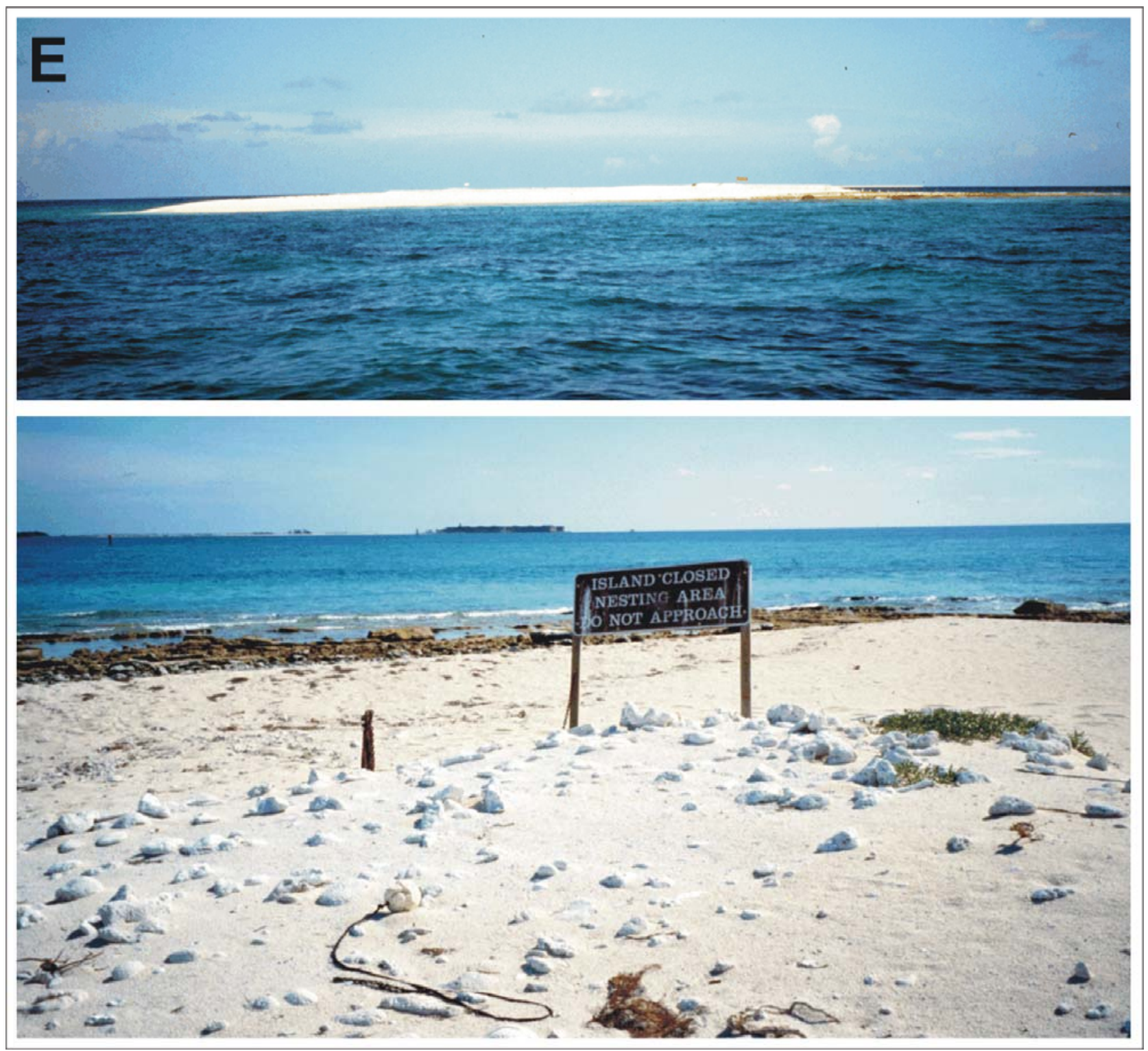

Figure 3E. Hospital Key; The top photo shows the slight aerial portion of Hospital Key, and the bottom photos shows a sign deterring trespassing to protect nesting birds (photos by Rebecca Beavers) (very high vulnerability). 


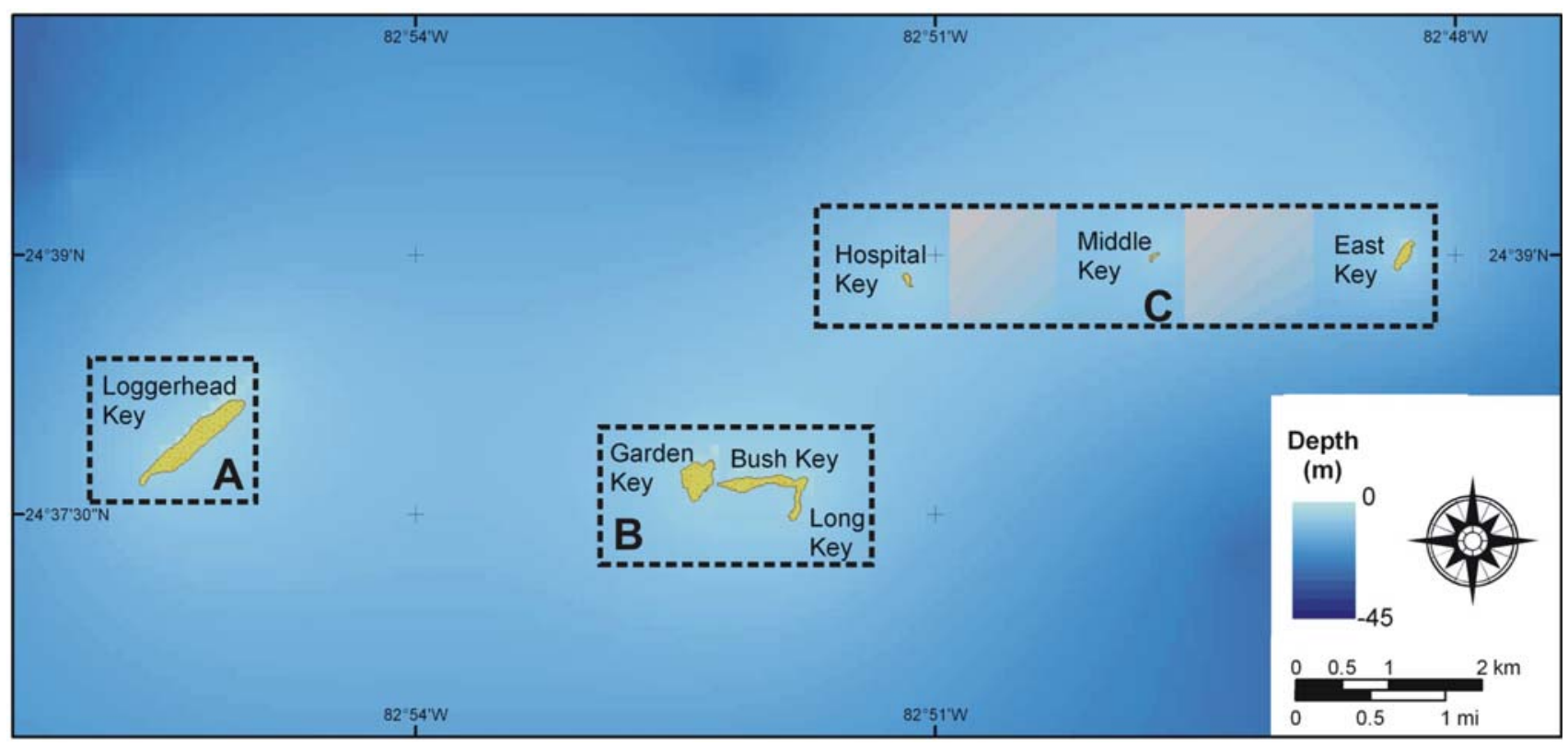

Figure 4. Index map for historic shoreline change figures. Click on a box for a detailed view of historic shoreline change on A) Loggerhead Key, B) Garden Key, Bush Key, and Long Key, and C) Hospital Key, Middle Key, and East Key. Grey shaded areas are water and have been removed from the shoreline change figure. 


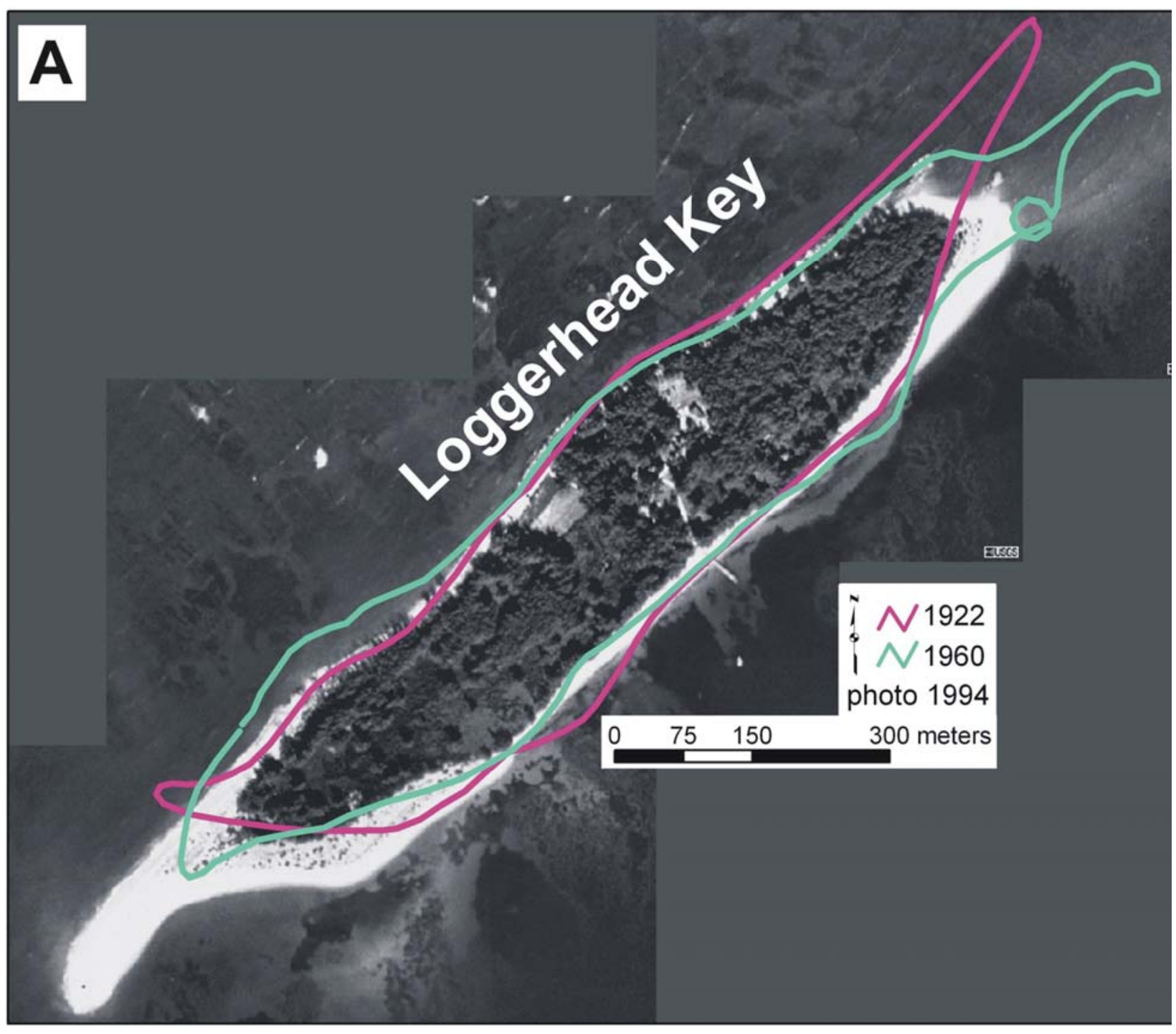

Figure 4A. Historic shoreline change for Loggerhead Key. 


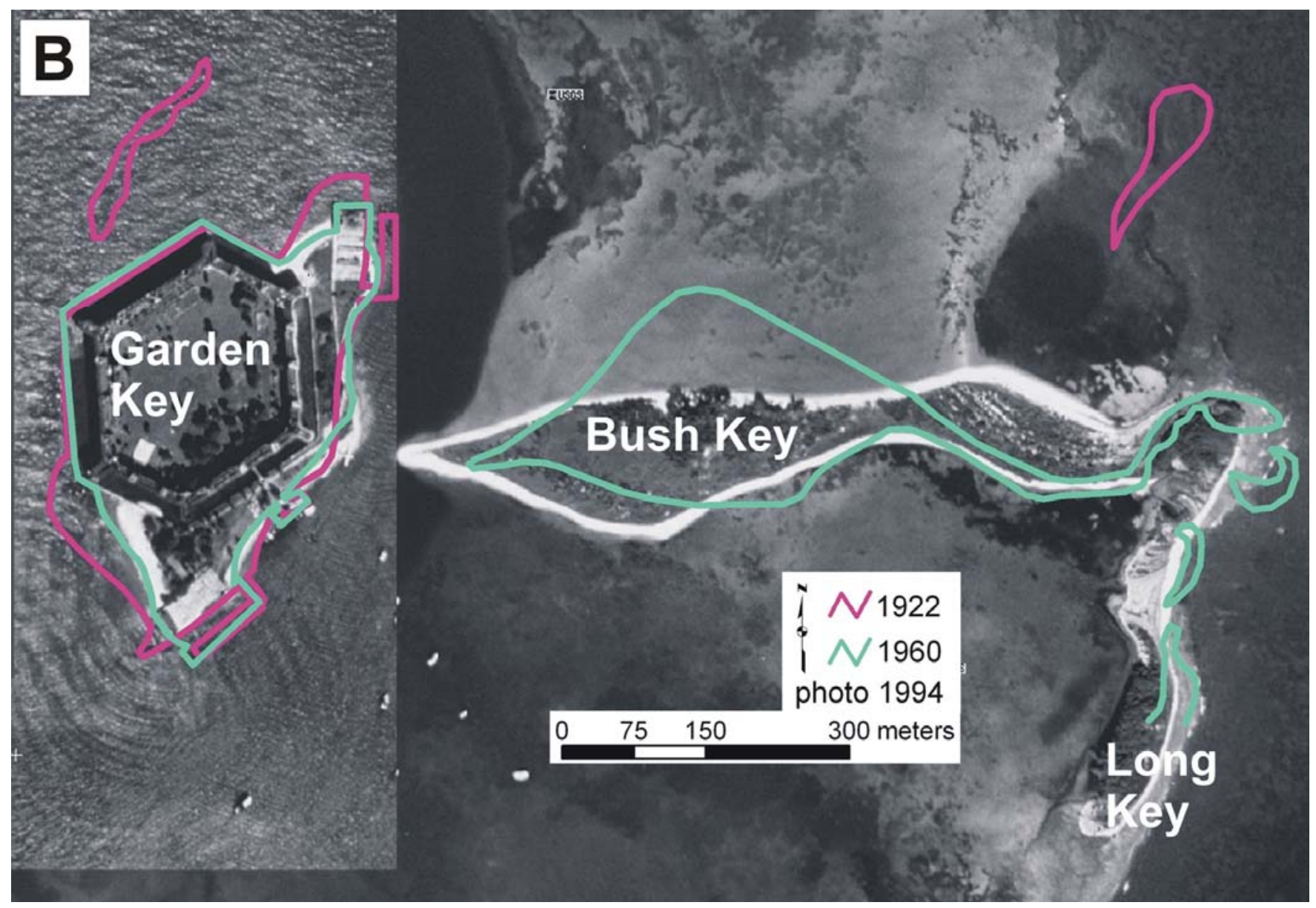

Figure 4B. Historic shoreline change for Garden Key, Bush Key, and Long Key. 


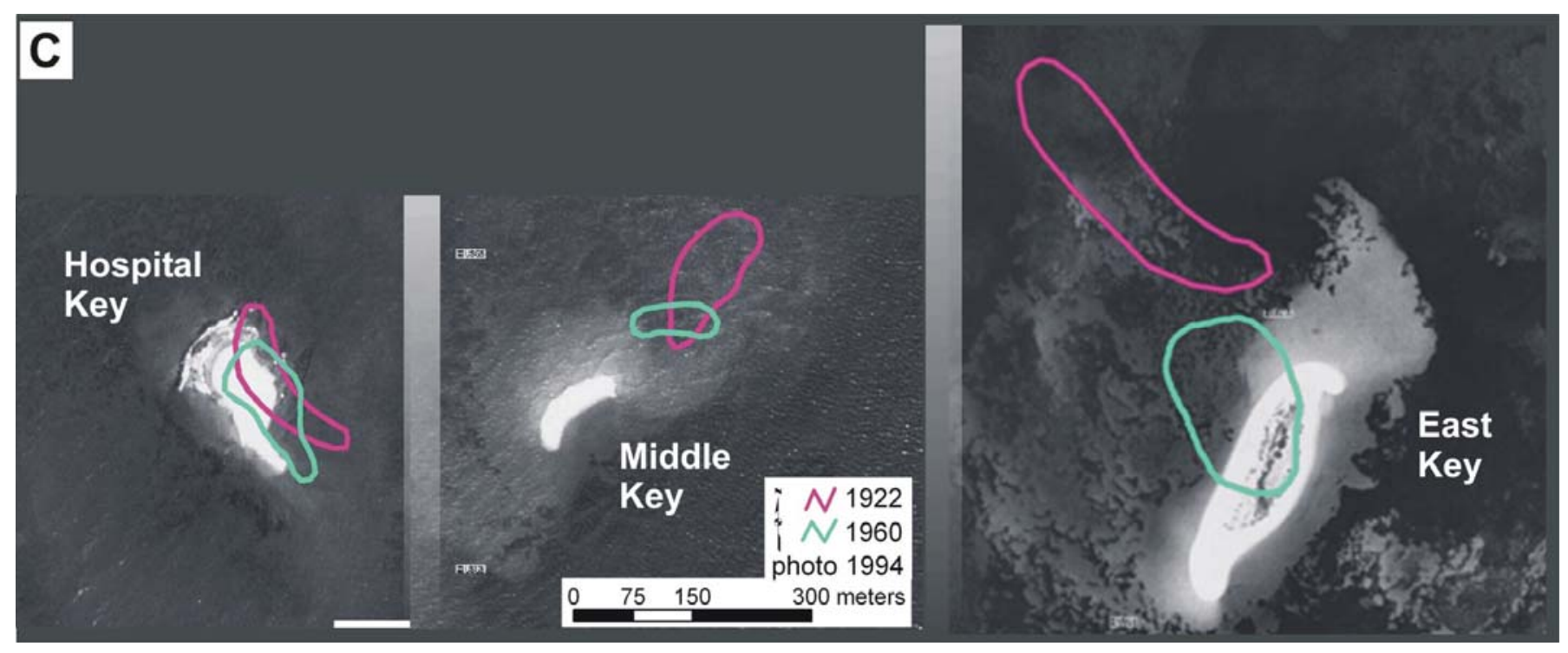

Figure 4C. Historic shoreline change for Hospital Key, Middle Key, and East Key. 


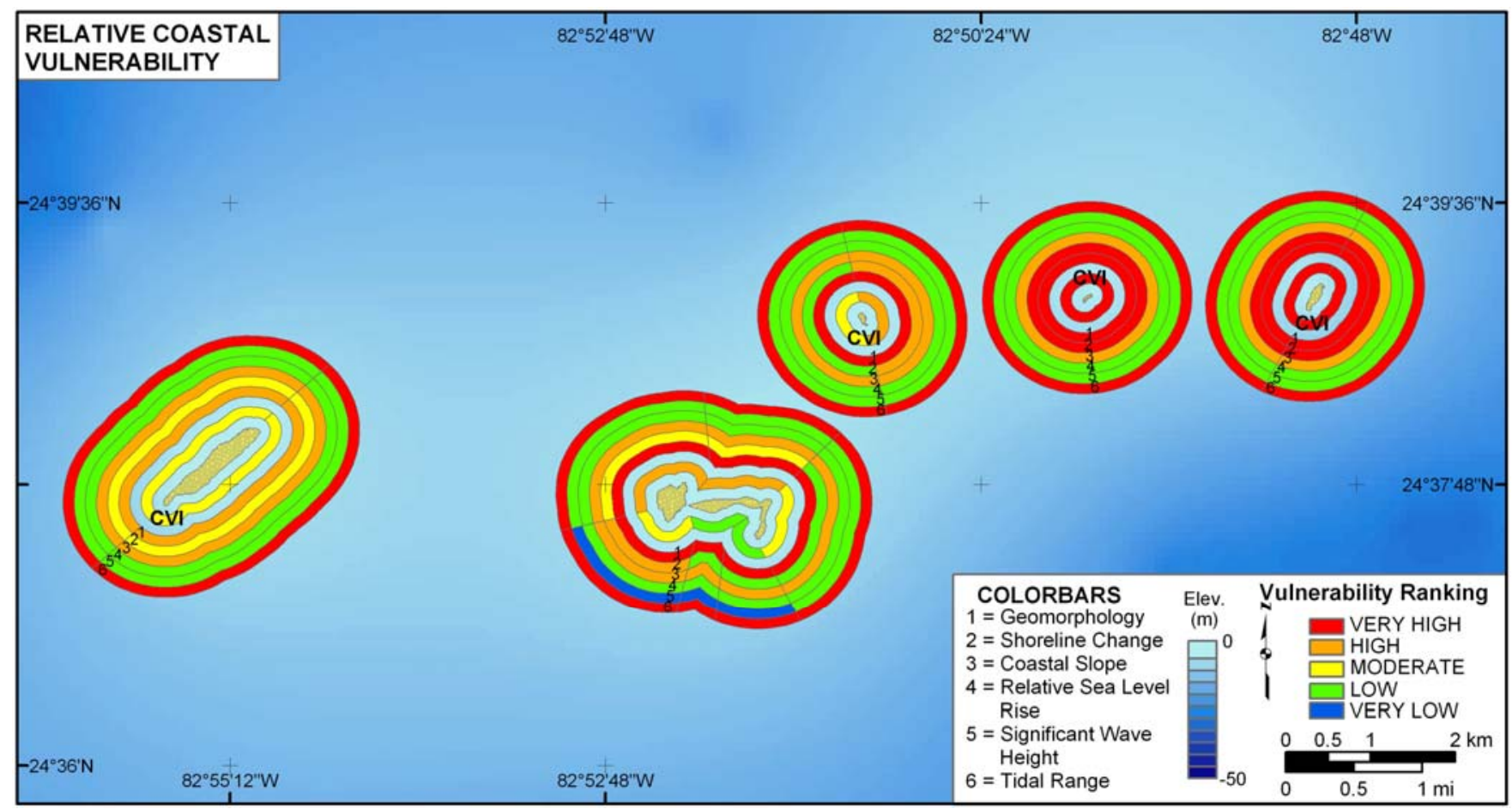

Figure 5. Relative Coastal Vulnerability for Dry Tortugas National Park. The innermost color bar is the relative coastal vulnerability index (CVI). The remaining color bars are separated into the geologic variables (1-3) and physical process variables (4 - 6). The very high vulnerability shoreline is located on East Key and Middle Key where rates of shoreline change have been highest. The low vulnerability shoreline is located on the south side of Bush Key and the west side of Long Key, where wave energy is low. 


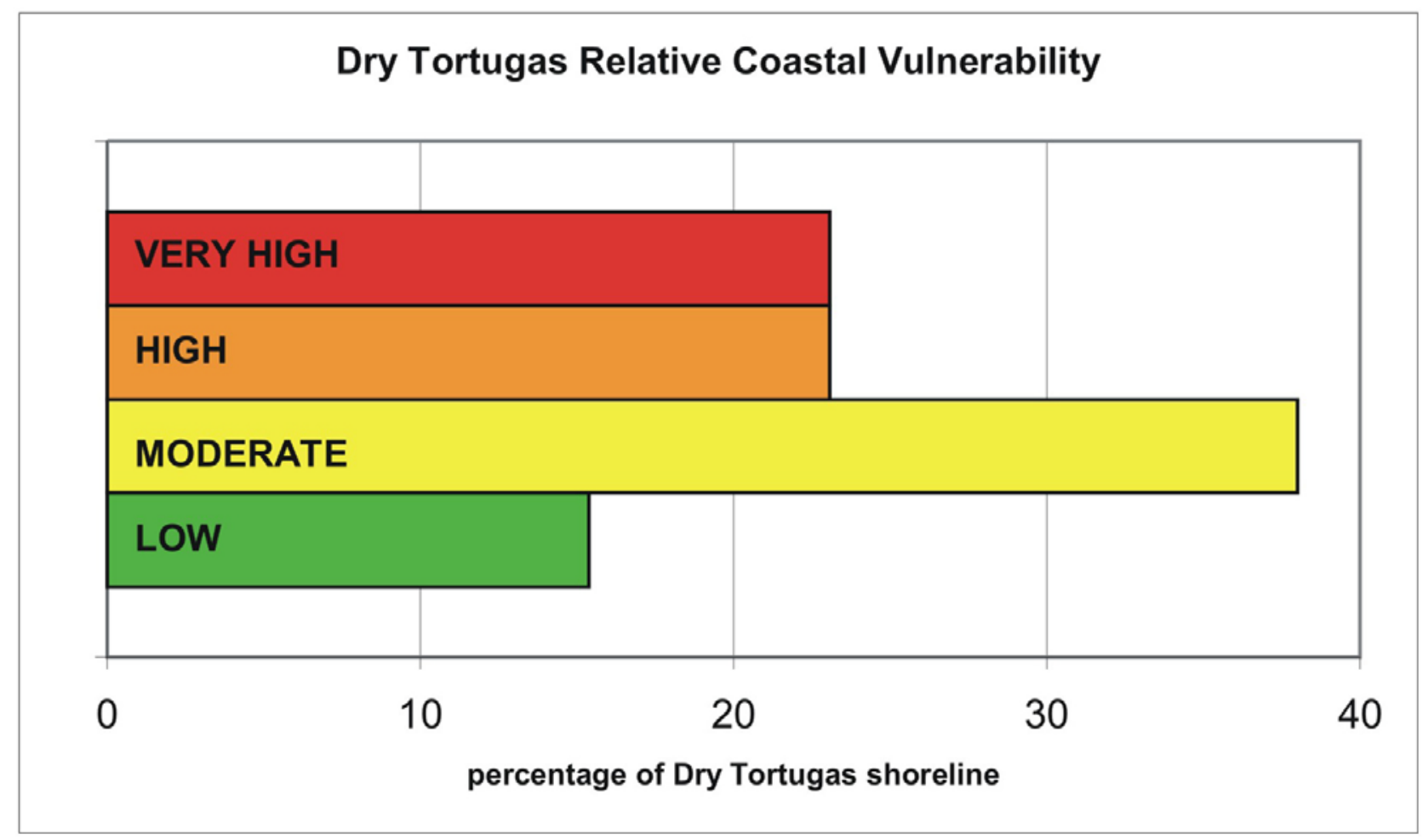

Figure 6. Percentage of Dry Tortugas shoreline in each CVI category. 
Table 1. Ranges for Vulnerability Ranking of Variables on the Atlantic and Gulf Coast.

\begin{tabular}{|c|c|c|c|c|c|}
\hline Variables & Very Low & $\begin{array}{c}\text { Low } \\
2\end{array}$ & $\begin{array}{c}\text { Moderate } \\
\mathbf{3}\end{array}$ & $\begin{array}{c}\text { High } \\
4\end{array}$ & $\begin{array}{c}\text { Very High } \\
5\end{array}$ \\
\hline GEOMORPHOLOGY & $\begin{array}{l}\text { Rocky } \\
\text { cliffed } \\
\text { coasts, } \\
\text { Fjords }\end{array}$ & $\begin{array}{l}\text { Medium } \\
\text { cliffs, } \\
\text { Indented } \\
\text { coasts }\end{array}$ & $\begin{array}{l}\text { Low cliffs, } \\
\text { Glacial drift, } \\
\text { Alluvial plains }\end{array}$ & $\begin{array}{l}\text { Cobble } \\
\text { Beaches, } \\
\text { Estuary, } \\
\text { Lagoon }\end{array}$ & $\begin{array}{c}\text { Barrier beaches, Sand beaches, } \\
\text { Salt marsh, Mud flats, Deltas, } \\
\text { Mangrove, Coral reefs }\end{array}$ \\
\hline $\begin{array}{l}\text { SHORELINE EROSION/ } \\
\text { ACCRETION (m/yr) }\end{array}$ & $>2.0$ & $1.0-2.0$ & $-1.0-1.0$ & $-2.0--1.0$ & $<-2.0$ \\
\hline COASTAL SLOPE (\%) & $>1.20$ & $1.20-0.90$ & $0.90-0.60$ & $0.60-0.30$ & $<0.30$ \\
\hline $\begin{array}{l}\text { RELATIVE SEA-LEVEL } \\
\text { CHANGE (mm/yr) }\end{array}$ & $<1.8$ & $1.8-2.5$ & $2.5-3.0$ & $3.0-3.4$ & $>3.4$ \\
\hline MEAN WAVE HEIGHT (m) & $<0.55$ & $0.55-0.85$ & $0.85-1.05$ & $1.05-1.25$ & $>1.25$ \\
\hline MEAN TIDE RANGE (m) & $>6.0$ & $4.0-6.0$ & $2.0-4.0$ & $1.0-2.0$ & $<1.0$ \\
\hline
\end{tabular}




\begin{tabular}{|c|c|c|}
\hline Variables & Source & $\begin{array}{c}\text { URL } \\
\text { (Not all sources are downloadable) }\end{array}$ \\
\hline GEOMORPHOLOGY & $\begin{array}{l}1994 \text { USGS Orthophotos } \\
\text { (DO00s) }\end{array}$ & http://terraserver.microsoft.com/ \\
\hline $\begin{array}{c}\text { SHORELINE } \\
\text { EROSION/ACCRETION (m/yr) }\end{array}$ & $\begin{array}{c}\text { Dry Tortugas shoreline } \\
\text { change data (1922-1994) } \\
\text { digitized in house from T- } \\
\text { sheets, aerial photos, and } \\
\text { nautical charts. }\end{array}$ & http://historicals.ncd.noaa.gov/historicals/histmap.asp \\
\hline COASTAL SLOPE (\%) & $\begin{array}{l}\text { NGDC Coastal Relief Model } \\
\text { Vol } 03\end{array}$ & http://www.ngdc.noaa.gov/mgg/coastal/coastal.html \\
\hline $\begin{array}{l}\text { RELATIVE SEA-LEVEL CHANGE } \\
\qquad(\mathrm{mm} / \mathrm{yr})\end{array}$ & $\begin{array}{l}\text { NOAA Technical Report NOS } \\
\text { CO-OPS } 36 \text { SEA LEVEL } \\
\text { VARIATIONS OF THE UNITED } \\
\text { STATES 1854-1999 (Zervas, } \\
\text { 2001) }\end{array}$ & http://www.co-ops.nos.noaa.gov/publications/techrpt36doc.pdf \\
\hline MEAN WAVE HEIGHT (m) & $\begin{array}{l}\text { North Atlantic Region WIS } \\
\text { Data (Phase II) and NOAA } \\
\text { National Data Buoy Center }\end{array}$ & $\begin{array}{l}\text { http://www.frf.usace.army.mil/wis/WISabout.html } \\
\text { http://seaboard.ndbc.noaa.gov/ }\end{array}$ \\
\hline MEAN TIDE RANGE (m) & $\begin{array}{l}\text { NOAA/NOS CO-OPS } \\
\text { Historical Water Level } \\
\text { Station Index }\end{array}$ & http://www.co-ops.nos.noaa.gov/usmap.html \\
\hline
\end{tabular}

